\title{
HORIZONS OF VULNERABILITY AND THE PROBLEM OF HUMAN DIGNITY: ETHICAL AND PHENOMENOLOGICAL ASSESSMENTS ${ }^{1}$
}

\author{
IGNACIO QUEPONS
}

\begin{abstract}
The paper suggests how a phenomenological account of vulnerability, in the context of moral emotions, may address the clarification of the problem of human dignity. In order to present this claim, the paper emphasizes the horizon dynamics involved in the emotional disclosure of the axiological sphere in Husserl's phenomenology, in regard to some essential aspects of the experience of feeling vulnerable. Afterwards, it is suggested how such consciousness of being vulnerable is connected to the realization of basic values, particularly, the very intrinsic value of human life.
\end{abstract}

The purpose of this paper is to suggest how a phenomenological reflection on the experience of vulnerability ${ }^{2}$ addresses the problem of human dignity. The phenomenological ethics inspired by the thought of Edmund Husserl emphasizes the importance of the constitution of moral character and subjective dispositions

1 A preliminary version of this paper was presented in the conference Persons and emotions, at the Phenomenology Research Center, South Illinois University, Carbondale. April 2016. I want to acknowledge professors Mariano Crespo, Anthony Steinbock, Jakub Capek and James G. Hart for their observations and criticisms. Additionally, I had the chance of discussing the project of a phenomenology of vulnerability which this paper belongs to, in different workshops organized at Charles University of Prague in between 2016 and 2017 with the support of professor Karel Novotný and Hans Rainer Sepp. I also would like to acknowledge the fruitful criticisms of professors James Mensch, Daniele De Santis and Darin McNabb.

2 Steinbock Anthony J., Moral Emotions, reclaiming evidence from the Heart, Northwestern University Press, 2014, p. 11.

https://doi.org/10.14712/24646504.2019.10

(C) 2019 The Author. This is an open-access article distributed under the terms of the Creative Commons Attribution License (http://creativecommons.org/licenses/by/4.0). 
as the main source of moral meaning. Compared with early formal account of morality, where Husserl followed Brentano's interpretation of the Kantian categorical imperative, ${ }^{3}$ his late reflections on Ethics emphasize emotive experiences such as personal love and vocation ${ }^{4}$ as the ultimate motivation for the moral action.

In this regard, the aim of my contribution is to stress, in accordance with discussions in current ethical debates on vulnerability, ${ }^{5}$ that a phenomenology of the condition of being vulnerable contributes to the reformulation of the principle of autonomy in terms of a relational-autonomy ${ }^{6}$ and to a different understanding of the notion of human dignity. ${ }^{7}$ Furthermore, as an alternative to the idea of dignity derived to a certain extent from the assumption of individual autonomy, in terms of the modern reception of Kantian moral philosophy, a philosophical reflection on the experience of vulnerability may contribute to the development of a "negative", but concrete, theory of dignity. ${ }^{8}$ My claim is that vulnerability, far from being an empirical and circumstantial condition of the human person, is an experience that may disclose dignity as the ultimate worth which under certain circumstances is subject to be harmed. Additionally, to feel vulnerable or to realize the vulnerability of others implies an implicit reference to the worth of the individual person as something endangered and in the need of being cared, which is essential for the recognition of a concrete sense of values beyond cultural or historical constrictions.

In order to suggest this description, the paper outlines three phenomenological aspects of the experience of vulnerability: a) vulnerability as involving an emotive, pre-reflective and non-thematic form of self-experience, b) vulnerability in regard to the emotive disclosure of our personal exteriority and the constitution of alterity and c) vulnerability as relative to "hostile environments" understood as

3 Hua XXVIII, p. 40.

4 Hua XLII, p. 353, p. 356 ss.

5 Cortina Adela, Conill Jesus, "Ethics of Vulnerability", in Masferrer Aniceto, García-Sánchez Emilio (eds.), Human Dignity of the Vulnerable in the Age of Rights, Ius Gentium, Comparative Perspectives on Law and Justice, vol 55. Springer, 2016.

6 Mackenzie Catriona, Dodds Susan, "Why bioethics need a concept of vulnerability", in International Journal of Feminism Approaches to Bioethics, vol. 5, no. 2, 2012, p. 40.

7 Cfr. Turner Bryan S., Vulnerability and Human Rights, Pennsylvania State University Press, University Park, 2006.

8 This notion is inspired by the Negative Theory of Justice developed by the Mexican philosopher Luis Villoro. According to Villoro, in comparison with the formal theory of Justice of John Rawls, it is possible to claim a concrete experience of justice through a "via negativa" as a concrete experience of values from their absence, in this case, the experience of injustice. A possible consequence of the phenomenology of vulnerability as a moral emotion is precisely to show a possible perspective for a theory of dignity consistent to Villoro's account of Justice in the context of Ethics and Political Philosophy. Villoro, 1997, 2007. 
negative possibilities of the life-world in regard to the emotional affection of being under threat. This threefold schema of the key-points of vulnerability aims to reframe a rationalistic based notion of moral autonomy, by stressing on the one hand the importance of the role of emotions in the self-awareness and on the other hand alterity as an essential horizon of the self-constitution of the person. Afterwards, the paper suggests the sketch of a negative theory of dignity taking as point of departure the dialogue between a phenomenology of vulnerability and two more recent authors who address a similar assessment on precariousness, vulnerability and the experience of values: Luis Villoro and Martha Nussbaum. While Villoro develops a negative and experience-based theory of justice ${ }^{9}$ in opposition to Rawls, Nussbaum offers a similar account of values based in a deep philosophical reflection on emotions and vulnerability. According to Nussbaum, to value objects and people is precisely what reveals our vulnerability. ${ }^{10}$ Both Villoro and Nussbaum sustain that the origin of values is related to our precarious condition or the possibility of losing something we care about.

Additionally, my claim is that the personal engagement involved in the vocation for the authentic life, presented by Husserl, especially in his late writings ${ }^{11}$, is essentially related to an undeniable sense of vulnerability, which constitutes, at the same time, a very important aspect of the concrete circumstances of moral decisions. Hence, vulnerability is understood as an essential interpersonal aspect of moral experiences, particularly, the experience of trust, personal love, and responsibility; it discloses the individual worth of the person, their dignity, as something grounded in the fragile set of interrelations and horizons of the concrete circumstances of their existence. ${ }^{12}$

Villoro Luis, Los retos de la sociedad por venir, Fondo de Cultura Económica, 2007.

10 Nussbaum Martha C., Upheavals of Thought: the intelligence of Emotions, Cambridge University Press, 2005, p. 42.

11 Hua XLII, p. 451.

12 In a certain sense, this presentation is an attempt to contribute to some ethical consequences of the idea of an ontology of the body in dialogue with other traditions and assessments, particularly, Judith Butler's remarks on a "common" corporeal vulnerability and the notion of precarious life as the possibility of a philosophical ethics (Butler Judith, Precarious life, the power of mourning and violence, Verso, New York, 2004). 


\section{Husserl and the possibility of a phenomenological ethics of vulnerability}

Along the different moments of his intellectual development, Edmund Husserl, founder of the phenomenological tradition, attempted to provide philosophical foundations of morality based on his phenomenological account of the emotive experience. According to Husserl, emotions are essential to the disclosure of values and, in consequence, are an undeniable source of knowledge for the clarification of sense of the moral experience. ${ }^{13}$ In order to sustain his point, Husserl described the emotions as complex lived-experiences ${ }^{14}$ conformed by intentional meanings consistent with logical judgment and a formal explanation of axiology. ${ }^{15}$ However, inasmuch the very foundation of his theory is based on a principle of experience, Husserl's late investigations on this topic lead him to a progressive emphasis on the notion of human person as ultimate ground for his ethics. ${ }^{16}$ The last stage of Husserl's intellectual development emphasizes the experience of the person as a complex of habitualities ${ }^{17}$ [Habitualitäten] and a progressive unity of individualization as a subjective moral agent. ${ }^{18}$

Furthermore, and this is especially remarkable in Husserl's late reflections on Ethics, the experience of alterity and the individual worth of others becomes an undeniable aspect of any ethical consideration. ${ }^{19}$ The core of his reflection in this regard is the experience of personal love as the ultimate source of moral evidence. Nevertheless, a neglected aspect of many Husserl's critics is the importance of the embodiment in the phenomenological account of a person and its consequences for a phenomenological account of moral experience. The personal subjectivity is the result of a complex of habitual forms of intentional references that involves a practical understanding of the surrounding world, informs the horizon of the perceptual experience, and performs its activities through its own lived-body. The sense of property over the body plays a double sense: on the one hand nothing belongs to me as my own property as much as my own body, ${ }^{20}$ but on the other hand, my body conforms to the horizon of my own exteriority, and within a permanent

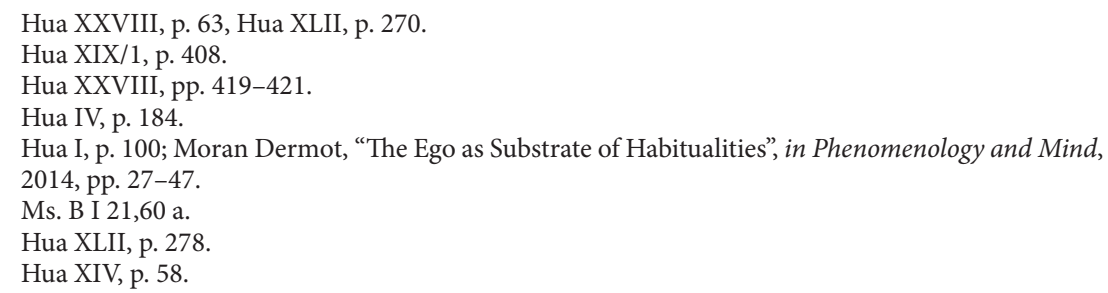


exposition to eventual harm from the surrounding world of the hazard inherent to the interaction with others. The embodiment of my existence constitutes at the same time the concretion of my individual life in the world and the fundamental source of my vulnerability. ${ }^{21}$ Furthermore, compared to the Kantian and formalist accounts of ethics that ground the notion of dignity on the autonomy of reason, the phenomenological approach is based on a constitutive and intuitive account of the human person as basis of the development of the ethical assessments, it cannot deny the affective and precarious condition as a moment of a person's worth. ${ }^{22}$ Thus, if it is possible to find such a kind of idea of human dignity, it should not come from the abstraction of the concrete and fragile circumstances of human existence, but as it is disclosed by the concrete experience.

\section{Horizons of vulnerability}

To be vulnerable is the condition of being subject to harm. It does not mean just our mere physical fragility, but, from the point of view of our moral and emotional experience of being vulnerable, rather also the possibility of an integral breakdown that compromises our entire life as a meaningful life, including all the objects, ideas and people that matter for us. ${ }^{23}$ Moreover, the main aspect that reveals the experience of vulnerability in the context of moral emotions is the progressive awareness of the limits of our life and how such fragility discloses the value of what we are as individuals. The awareness of our vulnerability implies a sense of affective anticipation of possible failures that compromise our existence. In this regard, human vulnerability, even in the case of the capability of being bodily harmed, is essentially a moral issue that covers a spectrum wider than mere physical fragility. However, to be vulnerable not necessarily implies something negative. A few contemporary authors have emphasized the importance of the recognition of an "ontological" condition of our embodied humanity. ${ }^{24}$

21 Butler J., Precarious Life, the power of mourning and violence, op. cit., p. 26.

22 Other authors have suggested similar positions regarding the insufficiencies of the Kantian notion of respect, and have claimed the need to integrate emotional experience as an essential moment of a person's worth (Dillon Robin S., "Self-Respect: Moral, Emotional, Political", in Ethics, 107 (2), 1997, pp. 226-249).

23 Harris George, Dignity and Vulnerability: Strength and Quality of Character, University of California Press, 1997.

24 Fineman Martha A., "The vulnerable subject and the responsive state", in Emory Law Journal, vol. 60, no. 2, 2010, pp. 251-257; Turner B. S., Vulnerability and Human Rights, op. cit.; Butler J., Precarious life, the power of mourning and violence, op. cit.; Butler Judith, Frames of War: When Is life 
However, in order to address the "human" sense of being vulnerable, it is important to consider human life as existing through horizons of possible actions and expectations that compromise projects and values, which is the source of the moral meaning of the realization of vulnerability. The expression horizon, in this context, means the field of intentional implications of sense where each lived-experience refers, while it occurs, to a variety of implicit co-intentions [Mitmeinungen] that anticipate and contribute to the process of explication of meaning as a result of such complex of references. ${ }^{25}$

On one hand, the experience of trust, particularly the kind of trust involved in personal love, ${ }^{26}$ discloses our condition of precariousness, and the meaning or significance of our lives - as well as the people who matter to us - through non-thematic horizons of different levels. On the other hand, the reflection on vulnerability as a disclosure of the person, far from being a mere sign of weakness, could be understood also as a source of strength of character ${ }^{27}$ and the reflection on this condition may allow us to bring a more concrete account of morals based on human experience as it is.

Vulnerability does not necessarily mean mere weakness, but the possibility of the affirmation, through the awareness of such fragility, of a purpose for life beyond the mere survival instinct. The force for overcoming an integral breakdown of our lives may come from our experience of taking care of and loving other people, and the fact that others may care about us. ${ }^{28}$ Moreover, it belongs to the sense of our vulnerability to understand the individual existence of certain situations, especially our lives and the life of another person, as something that matters enough to keep fighting for it after a tragedy.

In order to claim such possibility, it is important to explain how the anticipation of the possible failure of a project, or even the complete failure of all our enterprises, involves an implicit sense of awareness of our condition that discloses, in a practical way, the worth of our lives and the life of the people important in our lives. ${ }^{29}$

Grievable, Verso, London, 2016; Nussbaum M. C. Upheavals of Thought: the intelligence of Emotions, op. cit.

25 Walton Roberto, "Función y significado de la intencionalidad de horizonte", in Pintos María Luz, López José Luis González, Congreso Fenomenología y Ciencias Humanas, Santiago de Compostela, 24-28 September, 1996; Steinbock Anthony, Home and Beyond. Generative Phenomenology after Husserl, Northwestern University Press, 1995, pp. 104-109; Geniusas Saulius, The Origins of the Horizon in Husserl's Phenomenology, Dortrecht, Springer, 2012.

Harris G., Dignity and Vulnerability: Strength and Quality of Character, op. cit., p. 32.

Ibid., p. 130.

29 The worth of our lives is not thematized but referred as an implicit assumption revealed by the activity of "Care". 
a) "Care" as the horizon of self-givenness and the limits of self-determination.

The first step in our consideration of vulnerability is to show how this experience discloses our subjective experience as our own personal lives. According to Husserl, the transcendental constitution of the person involves a lived-body as principle of movement and interaction with others. In this regard, Judith Butler's recent remark on the ontology of the body as essentially vulnerable is entirely coherent with a phenomenological account of the lived-body: "In its surface and its depth, the body is a social phenomenon: it is exposed to others, vulnerable by definition" 30 . The lived-body manifests my own personal exteriority not only as expression of myself but especially as exposure of myself to others. The surrounding world is given to my experience through my body but not as a mere means, it rather compromises my personal existence since my skin is a permanent field of external affection. Thus, the embodied agency involves an active participation of my body.

However, vulnerability is not reduced to the obvious affection and fragility of my body, but from the point of view of the lived-experience, to realize such vulnerability is related to a kind of pre-reflective self-awareness of the worth of my life. The awareness of the possibility of being harmed discloses, in the form of a horizon, the personal life through the intertwining between the practical experience of care and the understanding of the exposition and fragility of my body as vulnerability of myself as the person who I am.

First of all, and before going into the phenomenological structure of the experience of care, it is important to remark that, according to Husserl, the constitution of personhood does not coincide with the immediate intuition of the "I" through reflection, but involves the progressive development of self-knowledge as a person, which is essential for the development of the subject as such. ${ }^{31}$

In this regard, the horizons of self-experience involve not only theoretical self-reflection, but especially a practical evaluation of our lives based on a pre-reflective understanding of what Husserl calls the "totality of lives", which is developed through different horizons. Therefore, the pre-reflective and progressive awareness of our lives as personal lives is disclosed through self-apperceptions and

30 Butler J., Frames of War: When Is Life Grievable, op. cit., p. 31.

31 "Jemand 'kennt' sich nicht, 'weiss' nicht, was er ist; er lernt sich kennen, Beständig erweitert sich die Selbsterfahrung, die Selbstapperzeption. Das 'Sichkennenlernen' ist eins mit der Entwicklung der Selbstapperzeption, der Konstitution des 'Selbst', und diese vollzieht sich in eins mit der Entwicklung des Subjektes selbst” (Hua IV, p. 257). 
affective horizons that Husserl sometimes identifies with the experience of moods or Stimmungen. 32

The moods, according to Husserl, are background tonalities and affective experiences that compose a unified stream of feelings which may be interpreted as engaging bodily resonances and temporal associations and expectations. The very idea of resonance might be understood in the context of mood, and following Husserl's descriptions, at least in two different ways: firstly as a sort of bodily concordance between bodily allure and emotive atmosphere; ${ }^{33}$ and secondly, as a sort of emotive kind of associative synthesis connecting actual experience with our memories of similar experiences but based on the emotive aspects. ${ }^{34}$

The notion of "resonance" as "Nachklang" makes explicit the reference to the moods of the stream of consciousness as a form of "stream of feelings" lingering over time but in reference to the past; nevertheless, the propagation of the emotive environment and its coherence with the stream of feelings, may also awaken a kind of emotive expectation towards the future, as he suggests in the manuscript of 1931, where Husserl describes the experience of an emotive anticipation of life as a totality through the experience of "care" [Sorge].

With this expression, Husserl means precisely an affective outline of the total life. Such an outline is based on the progressive structure of a continuous antic-

32 Despite the fact that Husserl did not offer a systematic account of the experience of moods as affective horizon, there are several descriptions, especially in his unpublished manuscripts, where Husserl referred to such experience. The most important texts where we may find phenomenological descriptions of the experience of moods are his notes on Stumpf's idea of attention, written right before the Logical Investigations, section 15 of the Fifth Logical Investigation, some of the texts of 1911 to 1914 collected in the unpublished project Studien zur Struktur des Bewusstseins (Cfr. Vongehr Thomas, "Husserls Studien über Gemüt und Wille", in Mayer Verena, Erhard Christopher, Scherini Marisa (eds.), Die Aktualität Husserls, Alber Philosophie, Freiburg im Breisgau, 2011, p. 337; Melle Ullrich, Feeling and Value, Willing and Action: essays in the Context of a Phenomenological Psychology, Springer, 2015); the texts gathered into Husserl's late lectures on Ethics, and some late manuscripts of 1931 and 1934.

33 "Die Freude weckt auch in der Leiblichkeit eine Resonanz, sie breitet sich aus als zuständliches «Gefühl» und auch wenn ich nicht mehr den Wert in der intentionalen Freude genieße, bin ich «selig». Ich erlebe ein weites Wohlgefühl, das nicht nur überhaupt Lust ist, sondern den apperzeptiven Charakter hat einer durch jene (im Hintergrund noch fortwirkende und noch 'rege', eventuell aber später unbewusste habituelle Richtung) Freude erweckten glückseligen Stimmung; und dann weiter auch: das ganze Tempo des weiteren Lebens kann einen Erholung und eine Lustcharakter übertragener Art haben, der zurückweist auf jene frühere Freude" (Hua XXXVII, p. 343).

34 "Die Freude kann noch lange nachklingen. Ich bin noch in gehobener Stimmung wenn ich mich anderen Personen zuwenden" (A VI 8, 45 b). In this case, Husserl prefers the expression "Nachklingen" as a verb form of the possible substantive Nachklang for "resonance". 
ipation of experience grounded on former experiences. Care then is an emotive form that emerges from the horizon of possible failures and eventual corrections. ${ }^{35}$

Moreover, Sorge is not a kind of emotive anticipation and does not anticipate mere empirical contents but rather the totality of life as horizon through the understanding of our personal future, projected through significant expectation regarding the very meaning of our lives, as subject to failure.

The consideration of care as a kind of horizon is entirely coherent with Husserl's own reflections regarding the intentionality of moods and the idea of affective horizons of experience. However, compared to Heidegger's account of Sorge, care for Husserl contains an undeniable moral sense ${ }^{36}$ since it involves not only a pre-reflective concern for my personal future but also for the importance of the life of others as constitutive elements of the meaning of my personal life.

The anticipation of the failure of any possible project is an implicit recognition of the limitations of my life, but also, at the same time, a pre-reflective and practical awareness of myself as subject to harm. In contradistinction to the reflective movement that discloses transcendental subjectivity for the purposes of the philosophical clarification of the constitution of sense, in the epistemological context, there are practical modes of intentional reference that reveal through their own horizons the realm of the worth of our lives as personal and individual lives given before any theoretical account of our self. ${ }^{37}$ Compared with Kant, these emotive horizons of the individual person do not give us our personal subjectivity as an unconditional principle of reason but as a conditioned, individual life with personal circumstances. Nevertheless, the disclosure of the person and its intrinsic worth disclosed through the experience of care and the pre-reflective recognition of my vulnerability, is negative. With the concrete realization of vulnerability, my own dignity is disclosed in an indirect way as the possibility of the personal breakdown or the harm of those that are important to me. As long as I understand that I have something to lose, I am subject to being harmed, and since what is subject to being lost is unique and irreplaceable, the damage is irreversible, and my vulnerability acquires the constitutive form of the person I am. ${ }^{38}$

35 "Die Sorge ist der Gefühlsmodus, der aus der Modalisierung der Aktivität entspringt und aus der bestätigen Vorzeichnung des Horizontes möglichen Missligens, innerhalb dessen die Linien des doch voraussichtlichen und gewissen Gelingens, des Gelingenes unter Korrektur, verlaufen" (Ms. E III 6,3a).

36 Hua XLIII, p. 397.

37 Steinbock A. J., Moral Emotions, reclaiming evidence from the Heart, op. cit., pp. 11-26.

38 Cfr. Butler J., Precarious life, the power of mourning and violence, op. cit., pp. 19-49. 
b) Embodiment and alterity: vulnerability as an affective horizon of self-exteriority. Alterity, in the phenomenological context, is an important moment in the constitution of the individual person. In Husserl's late manuscripts on time-consciousness, the outline of the constitution of the alterity is suggested as taking its point of departure in the horizons of the primordial sphere..$^{39}$ Nevertheless, for the purposes of this investigation, it is important to show how the constitution of the lived-body, as a personal body, implies the interpersonal and social interaction because of its permanent exposure to the world and to others. The body is not the mere objectivation of subjectivity but the sign of its self-exteriority. Additionally, its "mundanization" through the embodiment is that which allows the possibility of the concrete sense of the transcendence of others. ${ }^{40}$

The original experience of the other is grounded on the experience of my own exteriority as subject to being affected by others, and the apperception of the body of the others in the same terms. Moreover, since the other experiences my body precisely in the way I experience his or her body, I can realize how vulnerable he or she is in the same way. ${ }^{41}$

However, an often unremarked and important aspect of the constitution of the intersubjective sphere, in the transcendental phenomenology, as interpersonal sphere, is the role of affective horizons in the formation of a common environment or emotional atmosphere. The experience of the emotive horizon appears through the phenomenon of a resonance of the environment in my body. Husserl usually describes such resonance as the mere subjective affection of the environment. Nevertheless, since the body is at the same time the expression of my disposition and exteriority to the surrounding world, such resonance may be experienced in the context of vulnerability as the bodily expression of my feeling exposed to harm.

On the other hand, if the Stimmungen may also be described, not only as emotional subjective conditions but as emotive resonances constituting a connection between localized bodily sensations and the emotive environment, then the emotive horizon, in this case of "care", involves not only temporal expectations but emotive resonances intertwined with our bodily experience. For instance, while describing the affective experience in the Fifth Logical Investigation, Husserl himself mentions that "A sad event, likewise, is not merely seen in its thing-like content and context, in the respects which make it an event: it seems clothed and colored with sadness. The same unpleasant sensations which ego refers to and locates in itself (the pang in the hearth) are referred in one's emotional conception to the

\footnotetext{
39 Hua Mat VIII, p. 53.

40 Hua XIV, pp. 414-421.

41 Hua XIV, p. 438.
} 
thing itself" 42 . This suggests that the "coloration" of the environment that belongs to the mood of being sad, and the coloration of the event is referred in a certain way to the bodily affection.

Moreover, the Stimmung then might be understood not only as a mere coloration of the surrounding world, not as the mere resonance of the present to former experiences through affection, but it could also be understood as involving an emotive and passive reference to a possible future regarding the worth of our entire lives. Since the form of such disclosure is through the anticipation of our failure, and within it, the essential possibility of failing in our projects, ${ }^{43}$ the reach of our vulnerability affects, from the very beginning, the primordial constitution of our body as a body exposed, beyond our control, to the environment and to others. ${ }^{44}$ Furthermore, the anticipation of harm is not a mere possibility given through the emotive and pre-reflective character of Sorge, but is consistent with a complex of different horizons of passive synthesis that relates the possibility of failure, and the disposition to be harmed, with emotive affectations of our body, that appear as trembling or resonances.

What we wish to emphasize here is that such implication takes place through an embodied intentionality. The vulnerability is not the mere anticipation of failure but the anticipation of harm, which is a negative accomplishment of our practical intentionality. Then, harm is not just an affection of pain and suffering but frustration of a practical intention, the sudden unpleasant stopping of the free movement of the body and its practical aims.

However, perhaps the most important aspect of vulnerability as a moral emotion is its relation to the experience of trust. Vulnerability reveals the worth of myself, in the personal sense, through the anticipation of the failure of the projects that matter to me and the experience of my lived-body as subject of continuous external affection, and harm. Nevertheless, as Steinbock has remarked, inasmuch as trust constitutes a fundamental moment of our interpersonal experience, there is an essential condition of being vulnerable to the deception of the others that may involve not only our personal lives but also the life of the people that matter to us. Still, becoming vulnerable in the experience of trust is an unavoidable condition since, according to Steinbock, trust implies not only a disposition but an essential binding to another, "exposing ourselves or dis-posing ourselves by being bound

\footnotetext{
Hua XIX, p. 408.

Cfr. Ms. A VI 34 19a.

4 Cfr. Plessner Helmuth, Ausdruck und menschlische Natur, Gesammelte Schriften, VII, Suhrkamp, 2003, pp. 227-229.
} 
to another in trust reveals us as vulnerable. Vulnerability is essential to the trust experience" 45 .

The vulnerability of trust presupposes the two former moments according to our explanation so far. There is: a) the emotive anticipation of the failure of the projects we are engaged with, and within the emotive self-awareness as negative horizon of that we are afraid to lose; b) the body as permanent exposition of myself to others revealed through emotive resonances and the apperception of tonalities of the environment when we feel threatened.

At the same time the experience of trust reveals a dimension of vulnerability as a pre-reflective horizon of myself. I bind my own project to the other by revealing myself, though as vulnerable.

Thus, as Steinbock also suggests, trusts involves also to "proffer myself to another in an open future toward that which the trust is directed, as being bound to this other person" and in consequence, "[...] Trusting is the temporalizing movement of 'offering-ahead', allowing the trust to go before me or pointing the way forward as in a prolepsis. This temporalizing movement is as well, a pro-offering in the sense of a great-offering; I give myself over to another in trust toward an open future" 46 .

The emotive and practical disclosure of my personality through the horizon of care is revealed in the experience of trust as a positive engagement of my vulnerability. However, precisely what gives to this temporalizing movement its moral commitment as a "great offering" is that what I am offering toward an open future is nothing but my own dignity.

c) Horizons of vulnerability and the "hostile environments".

Finally, vulnerability shows how concrete and personal subjectivity is intrinsically embedded and immersed in the world as horizon of its own constitution. The affective horizon is an essential moment of the co-constitution of subjectivity and the surrounding world. Vulnerability is essentially circumstantial and relative to the different contexts of experience. This circumstantial and empirical aspect of vulnerability is one of the reasons out of which the Kantian Moral Philosophy considers vulnerability as morally irrelevant. However, this condition of being exposed to the world is an undeniable anthropological dimension of the human person. As Helmuth Plessner remarks, humans do not stand in their center but find them-

45 Steinbock A. J., Moral Emotions, reclaiming evidence from the Heart, op. cit., p. 207

46 Ibid., p. 205. 
selves always outside themselves, ${ }^{47}$ and perhaps such eccentricity is at the same time the very reason of our need for moral orientation. The vulnerability of our social bonds is the reason for our claim for a moral perspective. Nevertheless, in order to address our concrete problems as human people, such moral reflections should consider our concrete condition as precarious beings in a hostile world as a starting point.

On one hand, the unity of the lived-body itself is a core of an ongoing process of explication of sense through horizons. By following Husserl's descriptive notions we may point out an inner horizon explicating the unity of the kinesthesical nexus related to the individual body in question. On the other hand, there is an external horizon related to the surrounding world. Husserl does not describe such external horizon of the lived-body; however, it is possible to suggest that such "limit" corresponds not only to the physical limits of the corporal body but to the resistance to the free flow of the self-motivated movement. In this regard, such limit linked to the sense of invasive affectation of the environment, could be understood precisely as the horizon of vulnerability.

Moreover, as I already mentioned at the beginning of the paper, since the harm is not mere sensible pain nor suffering, it may be understood also as the frustration of a passive expectation derived from an unexpected and unpleasant affection. Therefore, the harm is mainly experienced as the confirmation of the failure of a practical aim grounded on the tendency of lived-body movement, simultaneously experienced with an invasive lived-experience. The suffering that belongs to the lived-experience of being harmed, is not independent of a sense of frustration thus, even the sensible pain associated to the experience of suffering harm is not a mere sensitive isolated lived-experience but it is surrounded by several layers of associative synthesis and always in the context of a kinesthesical motivation.

Furthermore, in his recent phenomenological investigations regarding the experience of pain, Agustín Serrano de Haro has also noticed how important is to consider the motion [Regung] of pain in the description of such experience:

The pain is always describing a trajectory, for the moment attentional, but it may be being varying, either in degree, or in its corporal diffusion, or in its quality or even in its own aversive impact. We may perhaps claim that the pain is in movement, that it

47 Plessner Helmuth, Die Stufen des Organischen und der Mensch. Einleitung in die philosophische Anthropologie, Berlin/Leipzig, 1928, p. 424. 
is always in itself a "motion" (Regung). Whatever that may start as sudden shock and commotion turns after as affliction that lingers and changes. ${ }^{48}$

The described trajectory or route, so to speak, of the pain is linked to the kinesthesical nexus, which is, at the same time, the condition of possibility of a bodily passive anticipation of the harm. Additionally, after a painful experience not only a reflective memory of the unpleasant event remains but an affective resonance linked to the bodily awareness may derive in the progressive realization of my own condition as something vulnerable.

Finally, the horizon of vulnerability implies a third level: the loss of control over the circumstances. The self-motivated movement and the progressive confidence of the "control" over my movement brings out the configuration of the perceptual field according to a familiar style through which the surrounding world appears to me. Such control over my body and the field of display of my movements progressively produces a sense of "control" over the circumstances. The resistance as external horizon defining the limits of the self-motivated movement is at the same time the expression of my lack of control.

\section{From the phenomenology of vulnerability to a negative theory of human dignity}

As we have attempted to show, vulnerability may be considered an instance of disclosure of the individuality of the person and its intrinsic worth as a person revealed through emotive experiences and not as derived from the idea of practical reason. According to Husserl, the primordial constitution of values belongs to the sphere of emotive experience. In this way, the value of the person should be, in consequence, disclosed through a kind of emotive experience. Nevertheless, the experience of values does not necessarily imply the actual presence of value as such; in some cases, it is possible to realize the experience of value through its patent absence. ${ }^{49}$

48 Serrano de Haro Agustin, "Atención y dolor. Análisis fenomenológico", in Serrano de Haro Agustin et. al. Cuerpo vivido, Encuentro, 2010, p. 136.

49 Cfr. Villoro L., Los retos de la sociedad por venir, op. cit., p. 20; Villoro Luis, El poder y el valor, Fondo de Cultura Económica, 1997, p. 26; Marin Esteban I., Del acto social al deber social Bases fenomenológicas para una ética social y política, Doctoral Thesis, UNAM, 2015, p. 96. 
Vulnerability reveals our condition as precarious beings, which, following authors such as Judith Butler or Emmanuel Levinas, ${ }^{50}$ is precisely that which obliges us to take responsibility:

Precariousness has to be grasped not simply as a feature of this or that life, but as a generalized condition whose very generality can be denied only by denying precariousness itself. And the injunction to think precariousness in terms of equality emerges precisely from the irrefutable generalizability of this condition. ${ }^{51}$

Therefore, vulnerability is the negative expression of the worth of each individual life, especially evident in those marginalized members of the community, and the indirect reference to a universal value of humanity in Kantian terms. To feel compassion, in consequence, does not necessarily mean just to sympathize with the suffering of others, but to realize how such fragility discloses a common possibility of humanity ${ }^{52}$ and how it may constitute a condition of possibility of ethical encounters, recognitions, and a concrete perspective for ethical social bonds. Our experiences of vulnerability may reveal then the worth of what our lives as humans actually means, in its concrete individuality.

\section{Conclusions}

The description of vulnerability suggested in this paper aimed to propose a consistent account of some elements related to Husserl's ethical account of the human person and emotions as an instance of disclosure of values. However, the description of dynamics of horizons of emotive experience opened the possibility of a phenomenological approach to the intrinsic value of people disclosed through the axiological significance of the fragility of human life.

From this phenomenological account, at the end, I suggested the possibility of a negative theory of dignity, taking in consideration some contemporary sug-

50 Levinas Emmanuel, Autrement quêtre ou au-delà de l'essence, Martinus Nijhoff/Kluwer, 1978.

51 Butler J., Frames of War: When Is life Grievable, op. cit., p. 22.

52 "A vulnerability must be perceived and recognized in order to come into play in an ethical encounter, and there is no guarantee that this will happen. Not only is there always the possibility that a vulnerability will not be recognized and that it will be constituted as the "unrecognizable", but when a vulnerability is recognized, that recognition has the power to change the meaning and structure of the vulnerability itself. In this sense, if vulnerability is one precondition for humanization, and humanization takes place differently through variable norms of recognition, then it follows that vulnerability is fundamentally dependent on existing norms of recognition if it is to be attributed to any human subject" (Butler J., Precarious life, the power of mourning and violence, op. cit., p. 43). 
gestions on ethics of vulnerability and the positions regarding the intelligence of emotions of Martha Nussbaum and the Negative Theory of Justice of Luis Villoro. For both authors, values are not only disclosed through positive experiences, but from the confirmation of the fragility of our axiological projects.

Ignacio Quepons is Associate Researcher at the Philosophy Institute, Veracruz University, Mexico. He has published extensively on Husserl's phenomenology of emotions, affective intentionality and ethics. From 2014 to 2016 he was a Postdoctoral Research Scholar and Instructor at the Philosophy Department, Seattle University. Currently he is working on a phenomenology of vulnerability and hostile environments. His most recent publications include, among others, "Intentionality of moods and horizon consciousness" in M. Ubiali and M. Wehrle (eds.), Feeling and Value, Willing and Action, (Springer, 2015), "Learning as recollection: Time and idealities in Plato and Husserl" in D. De Santis and E. Trizio, (eds.), Edmund Husserl between Platonism and Aristotelianism, The New Yearbook for Phenomenology and Phenomenological Philosophy, Vol. XV, (Routledge, 2017).

E-mail: iquepons@uv.mx 